\title{
MOVEMENT OBSERVATIONS ON THE GREENLAND ICE SHEET
}

\author{
By George Wallerstein \\ (Astronomy Department, California Institute of Technology, Pasadena, California)
}

\begin{abstract}
During the summer of 1955 certain positions on the Greenland Ice Sheet that had been established by the French in 1951 were redetermined by observations of the sun in order to measure the motion of the surface of the ice sheet. A motion of 774 meters in four years in a southerly direction was noted at the Central Station. A motion of 611 meters in a westerly direction was noted at the French Mile roo. The uncertainty of the measures is large when the time scale is as short as four years, and expeditions to this area are urged to remeasure these positions and extend the markers for future use.

Zusammenfassung. Im Verlauf des Sommers 1955 wurden gewisse Positionen von Grönlands Inlandeis, die von den Franzosen im Jahre $195^{1}$ etabliert worden waren, durch Beobachtungen der Sonne neu bestimmt, um den Lauf der Oberfläche des Inlandeises zu messen. An der Zentralstation wurde eine Fortbewegung von $774 \mathrm{~m}$ innerhalb von vier Jahren nach Süden hin festgestellt. Eine Fortbewegung von 6i $\mathrm{m}$ nach Westen hin wurde an der Franzosen "Mile roo" festgestellt. Die Unzuverlässigkeit der Massangaben ist gross für eine so kurze Zeitspanne wie vier Jahre, und nach diesem Gebiet ausgehende Expeditionen werden gedrängt, diese Positionen erneut zu messen und die Merkpfahle für zukünftigen Gebrauch auszudehnen.
\end{abstract}

DURING the summer of I955 Project "Jello", an expedition of the Snow, Ice, and Permafrost Research Establishment, visited the French Central Station on the Greenland Ice Sheet and then followed the French trail westward for I 90 miles $(306 \mathrm{~km}$.) to the vicinity of Camp VI. A number of accumulation stakes left along this route by the French in I95I were relocated. Owing partly to the smaller amount of accumulation at higher altitude ${ }^{\mathrm{T}}$ the length of stake remaining above the surface varied from about $2 \mathrm{~m}$. at a point 40 miles $(64 \mathrm{~km}$.) from the Central Station to as little as $13 \mathrm{~cm}$. for the stake 50 miles $(8 \mathrm{o} \mathrm{km}$.) further west. Fourteen o the nineteen stakes that might be expected to show above the surface were found. The other five were probably missed because of poor visibility, but possibly because they had been buried beneath the snow surface. The height of each was increased by $3.66 \mathrm{~m}$. so that the program of resurveying can be continued. Fig. I (p. 209) is a map of Greenland showing the entire route of Project "Jello". Positions are marked according to the SIPRE designation.

An accurate position was obtained at the Central Station. The latitude was obtained at local noon on four days and a total of eleven longitude observations were taken on three different days, four observations being taken before noon and seven after noon. The latitudes were computed by the usual reduction to the meridian of many observations and the longitudes were reduced by the "sine-cosine solution" as outlined in Bowditch."

At the French roo-mile point (5-140) one observation for latitude and three for longitude were taken. It was not possible to stop at each stake along the route because of the expedition time-schedule, but positions were obtained at stations 25 miles (40 km.) apart. The stakes between these stations were located by interpolation by dead reckoning, hence the large probable errors. The results are listed in Table I (p. 210), together with the French data for I95I.

\section{French Central Station}

The movement at the Central Station, $774 \mathrm{~m}$. in the 4 years $195 \mathrm{I}-55$, is in a southerly direction and not along the direction of surface slope which is about $245^{\circ}$ (from true north). The probable error of the French position in $195^{1}$ is $5^{\prime \prime}$ of latitude and $15^{\prime \prime}$ of longitude.* Thus the observed movement is three times the sum of the two probable errors of the latitude observations. Between 1950 and I95I the French noted a southward movement of 100 meters. ${ }^{3}$ Their time scale was too short for an accurate evaluation but the direction confirms the 1951-55 movement. Bedrock topography may influence the ice movement in this region.

* A. Bauer, personal communication. 
Seismic reflections indicate a ridge 20 miles $(32 \mathrm{~km}$.) west of the Central Station with a rise of $760 \mathrm{~m}$. in ro miles. ${ }^{4}$ This ridge may block westward movement of the ice and deflect it southward toward the central one of three deep bedrock channels found in this area. On the other hand, these observations may indicate an overall general southerly movement in the south-central portion of the ice sheet. It is evident that many additional observations are required. An accurate relocation of Mile 160 would be an important first step, as would the placing of stakes to the east of the Central Station.

\section{Mile 100}

The motion of 6 I I $\mathrm{m}$. in the four years $195^{\mathrm{I}-55^{-}}$at Mile roo was almost due west, indicating that surface slope is one of the important factors determining direction of motion at this point, halfway between the Central Station and the firn limit. Multiplying the average annual motion of $15^{2} \mathrm{~m}$./yr. by the total ice thickness, $2380 \mathrm{~m}$. at this point, yields a total flow of $36 \cdot 0 \times 10^{4} \mathrm{~m} \cdot 3 / \mathrm{yr}$. in a one meter cross section, if the velocity is assumed to be constant with depth.

If the ice sheet in this region is in equilibrium, this would have to be compensated by the total accumulation over the 100 miles $(16 \mathrm{r} \mathrm{km}$.) between Mile 100 and the Central Station. From a rough and incomplete analysis of the accumulation stake and pit study data Benson estimates the accumulation in this area to be approximately $49 \mathrm{~cm}$. of ice per year (personal communication). This yields a total accumulation of $8.43 \times 10^{4} \mathrm{~m} \cdot 3 / \mathrm{yr}$. This is too small by a factor of $4 \cdot 25$. Haefeli and Brentani, 5 by considering a velocity curve that is parabolic with depth and with no slippage on the bottom, derive a surface velocity of $50 \mathrm{~m}$./yr. in this vicinity. Correcting for their value of accumulation, which is too small by about a factor of $\mathrm{I} \cdot 6$, yields $82 \mathrm{~m}$./yr. This is in reasonable agreement with the observations. It must be noted that the estimated error of the 1955 longitude observations is two-thirds of the total motion. If the motion proves to be real it would indicate that there is less flow at depth than on the surface as in the Haefeli-Brentani model, or that the assumption of equilibrium is not correct.

\section{Central Station to Mile ioo}

The motions of the stakes between Mile 100 and the Central Station are so great that one is forced to attribute them to systematic navigational errors. The estimated internal errors are much smaller than the differences between the $195 \mathrm{I}$ and 1955 positions. The stake at Mile 160 was identified by digging down to the marker. The various heights above the surface and distances correlate with the French report (see footnote, Table I) so there is little chance of mistaken identification. A comparison of these motion data with bottom topography and ice thicknesses ${ }^{4}$ suggests no apparent cause for such large motion. Only a third survey can determine whether the navigational errors were made in $195 \mathrm{I}$ or 1955 .

It is obvious that this work is just a beginning and that a few years more are necessary in order to have a sufficient time scale. To facilitate further work, additional stakes have been placed between Mile roo and Camp VI and their positions located. These are listed in Table II (p. 2 Io) together with one French stake that was found and extended but for which the French gave no position. These positions were determined by one observation for latitude and three observations for longitude, one before noon and two after.

It is hoped that future expeditions visiting this area will relocate all these stakes with the greatest possible accuracy. The fact that these stakes are located in an accumulation area makes it necessary that they be found and extended every three years.

Acknowledgement is gratefully made to the Snow, Ice, and Permafrost Research Establishment for sponsoring this research and I am also very grateful for valuable discussions of the results with Mr. Carl S. Benson, leader of the expedition, and Professor Robert P. Sharp. The original map of Fig. I was kindly supplied to SIPRE by Expéditions Polaires Françaises. 


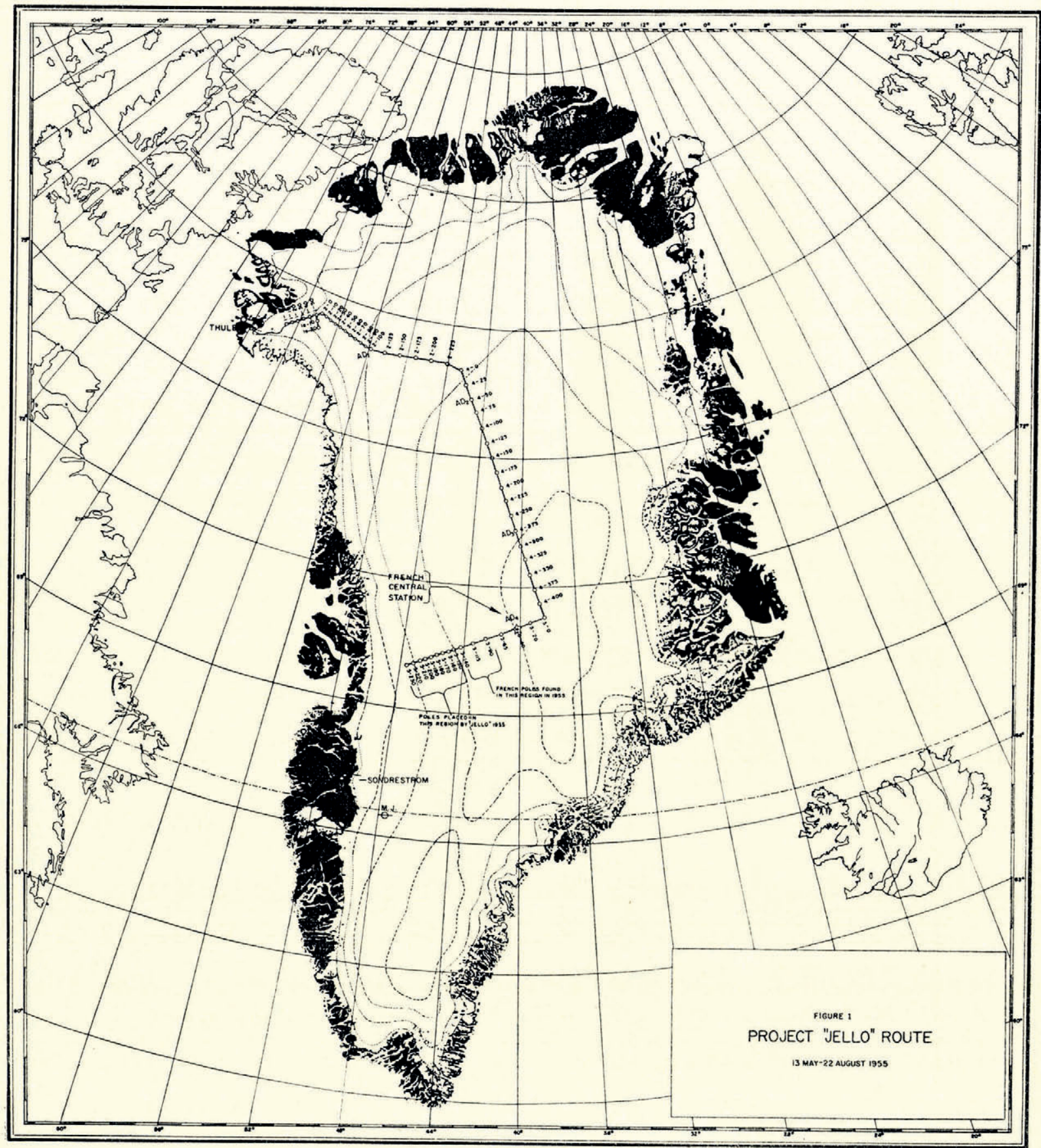

Fig. I 
TABLE I

\begin{tabular}{|c|c|c|c|c|c|c|c|c|c|}
\hline \multirow{2}{*}{$\begin{array}{c}\text { Mile } \\
\text { French } \\
\text { Designation }\end{array}$} & \multirow{2}{*}{$\begin{array}{l}\text { Number } \\
\text { SIPRE } \\
\text { Designation }\end{array}$} & \multicolumn{2}{|c|}{ I95I Position* } & \multirow[b]{2}{*}{ Latitude } & \multicolumn{2}{|c|}{$\begin{array}{l}\text { I955 Position } \\
\text { stimated }\end{array}$} & \multirow{2}{*}{$\begin{array}{c}\text { Estimated } \\
\text { error }\end{array}$} & \multirow{2}{*}{$\begin{array}{c}\text { Total } \\
\text { motion } \\
\text { kilometers }\end{array}$} & \multirow{2}{*}{$\begin{array}{c}\text { Direction } \\
\quad(\text { true } \\
\text { north })\end{array}$} \\
\hline & & Latitude & Longitude & & $\begin{array}{l}\text { stimated } \\
\text { error }\end{array}$ & Longitude & & & \\
\hline $\begin{array}{l}\text { Central } \\
\text { Station }\end{array}$ & $5-40$ & $70^{\circ} 54^{\prime} 50^{\prime \prime}$ & $40^{\circ} 3^{8^{\prime}} \mathrm{oo}^{\prime \prime}$ & $70^{\circ} 54^{\prime} 25^{\prime \prime}$ & $\pm 3^{\prime \prime}$ & $40^{\circ} 37^{\prime} 57^{\prime \prime}$ & $\pm 12^{\prime \prime}$ & $0 \cdot 774$ & $180^{\circ}$ \\
\hline$M$ I6o & $5-80$ & $70^{\circ} 4^{1} \cdot 3^{\prime}$ & $42^{\circ}$ I I $\cdot 6^{\prime}$ & $70^{\circ} 39 \cdot 8^{\prime}$ & $\pm 6^{\prime}$ & $42^{\circ}$ I $6 \cdot 5^{\prime}$ & $\pm I \cdot 5^{\prime}$ & $4 \cdot 15$ & $227^{\circ}$ \\
\hline M I 54 & $5-86$ & $70^{\circ} 3^{8 \cdot} \cdot 5^{\prime}$ & $42^{\circ} 22 \cdot 0^{\prime}$ & $70^{\circ} 37 \cdot 8^{\prime}$ & $\pm 5^{\prime}$ & $4^{\circ} 29 \cdot 5^{\prime}$ & $\pm \mathrm{I} \cdot \mathrm{O}^{\prime}$ & $4 \cdot 84$ & $254^{\circ}$ \\
\hline$M_{151}$ & $5-89$ & $70^{\circ} 37 \cdot 0^{\prime}$ & $42^{\circ} 30 \cdot 0^{\prime}$ & $70^{\circ} 36 \cdot 4^{\prime}$ & $\pm 4^{\prime}$ & $42^{\circ} 35 \cdot 5^{\prime}$ & $\pm \mathbf{I} \cdot \mathrm{o}^{\prime}$ & $3 \cdot 44$ & $263^{\circ}$ \\
\hline M I 49 & $5-91$ & $70^{\circ} 36 \cdot 0^{\prime}$ & $42^{\circ} 35^{\cdot} 0^{\prime}$ & $70^{\circ} 3^{6} \cdot 0^{\prime}$ & $\pm 4^{\prime}$ & $4^{2^{\circ}} 4^{1} \cdot 2^{\prime}$ & $\pm \mathrm{I} \cdot \mathrm{O}^{\prime}$ & $3 \cdot 85$ & $270^{\circ}$ \\
\hline $\mathrm{M} \mathrm{I}_{4} \mathrm{I}$ & $5-99$ & $70^{\circ} 34 \cdot 0^{\prime}$ & $4^{\circ} 5^{\circ} \cdot 0^{\prime}$ & $70^{\circ} 32 \cdot 8^{\prime}$ & $\pm 6^{\prime}$ & $43^{\circ} \mathrm{oo} \cdot \mathrm{o}^{\prime}$ & $\pm \mathrm{I} \cdot 5^{\prime}$ & $6 \cdot 55$ & $250^{\circ}$ \\
\hline $\mathrm{M}_{136}$ & $5^{-104}$ & $70^{\circ} 32 \cdot 0^{\prime}$ & $43^{\circ} \mathrm{o} 4 \cdot \mathrm{o}^{\prime}$ & $70^{\circ} 30 \cdot 8^{\prime}$ & $\pm 6^{\prime}$ & $43^{\circ} \mathrm{II} \cdot 5^{\prime}$ & $\pm \mathrm{I} \cdot \mathrm{O}^{\prime}$ & $5 \cdot 16$ & $245^{\circ}$ \\
\hline M I 34 & $5^{-106}$ & $70^{\circ} 30 \cdot 0^{\prime}$ & $43^{\circ} \mathrm{I} 2 \cdot \mathrm{O}^{\prime}$ & $70^{\circ} 29 \cdot 7^{\prime}$ & $\pm 2^{\prime}$ & $43^{\circ} 19 \cdot 0^{\prime}$ & $\pm \mathrm{I} \cdot \mathrm{O}^{\prime}$ & $4 \cdot 37$ & $262^{\circ}$ \\
\hline M 129 & $5^{-1}$ I I I & $70^{\circ} 29 \cdot 0^{\prime}$ & $43^{\circ} 22 \cdot 0^{\prime}$ & $70^{\circ} 28 \cdot 0^{\prime}$ & $\pm 2^{\prime}$ & $43^{\circ} 28 \cdot 5^{\prime}$ & $\pm \mathrm{I} \cdot \mathrm{O}^{\prime}$ & $4 \cdot 4 I$ & $245^{\circ}$ \\
\hline $\mathrm{M}_{118} 8$ & $5-122$ & $70^{\circ} 25 \cdot 0^{\prime}$ & $43^{\circ} 45^{\cdot} 0^{\prime}$ & $70^{\circ} 23 \cdot 9^{\prime}$ & $\pm 5^{\prime}$ & $43^{\circ} 50 \cdot 5^{\prime}$ & $\pm \mathrm{I} \cdot \mathrm{O}^{\prime}$ & $4 \cdot 06$ & $239^{\circ}$ \\
\hline $\mathrm{M}_{112}$ & $5^{-128}$ & $70^{\circ} 24 \cdot 0^{\prime}$ & $43^{\circ} 57 \cdot 0^{\prime}$ & $70^{\circ} 22 \cdot 0^{\prime}$ & $\pm 4^{\prime}$ & $44^{\circ}$ o6 $\cdot 7^{\prime}$ & $\pm \mathbf{r} \cdot 0^{\prime}$ & $7 \cdot 07$ & $23^{\circ}$ \\
\hline M I Io & $5^{-1} 3^{0}$ & $70^{\circ} 22 \cdot 0^{\prime}$ & $44^{\circ} 07 \cdot 0^{\prime}$ & $70^{\circ} 21 \cdot 0^{\prime}$ & $\pm 4^{\prime}$ & $44^{\circ}$ II $\cdot 5^{\prime}$ & $\pm \mathbf{I} \cdot \mathbf{O}^{\prime}$ & $3 \cdot 3^{2}$ & $237^{\circ}$ \\
\hline M 102 & $5^{-1} 3^{8}$ & $70^{\circ} 19 \cdot 0^{\prime}$ & $44^{\circ} 29 \cdot 0^{\prime}$ & $70^{\circ} 18 \cdot 2^{\prime}$ & $\pm 2^{\prime}$ & $44^{\circ} 29 \cdot 9^{\prime}$ & $\pm 0 \cdot 7^{\prime}$ & $\mathrm{I} \cdot 58$ & $200^{\circ}$ \\
\hline M roo† & $5^{-1} 4^{0}$ & $70^{\circ} 18^{\prime} 04^{\prime \prime}$ & $44^{\circ} 33^{\prime} 13^{\prime \prime}$ & $70^{\circ}$ 1 $8^{\prime} 03^{\prime \prime}$ & $\pm 4^{\prime \prime}$ & $40^{\circ} 34^{\prime}$ I $3^{\prime \prime}$ & $\pm 40^{\prime \prime}$ & .611 & $267^{\circ}$ \\
\hline
\end{tabular}

* From report of Expéditions Polaires Françaises to SIPRE, dated I April 1955.

+ This refers to the more northerly of two stakes at this location.

Mile Number
SIPRE
Designation
5-125*
$5-160$
$5-170$
$5-180$
$5-190$
$5-200$
$5-210$
$5-220$
$5-230$

TABLE II

\begin{tabular}{|c|c|c|c|}
\hline Latitude & $\begin{array}{l}\text { Estimated } \\
\quad \text { error }\end{array}$ & Longitude & $\begin{array}{c}\text { Estimated } \\
\text { error }\end{array}$ \\
\hline $70^{\circ} 32 \cdot 2^{\prime}$ & $\pm \cdot 4^{\prime}$ & $43^{\circ} 59 \cdot 5^{\prime}$ & $\pm \mathrm{I} \cdot \mathrm{O}^{\prime}$ \\
\hline $70^{\circ}$ I0' $3^{\prime \prime \prime}$ & $\pm 4^{\prime \prime}$ & $45^{\circ} 22^{\prime}$ I $\mathbf{1}^{\prime \prime}$ & $\pm 40^{\prime \prime}$ \\
\hline $70^{\circ} 06^{\prime} 17^{\prime \prime}$ & $\pm 4^{\prime \prime}$ & $45^{\circ} 43^{\prime} 12^{\prime \prime}$ & $\pm 30^{\prime \prime}$ \\
\hline $70^{\circ} 02^{\prime} 26^{\prime \prime}$ & $\pm 6^{\prime \prime}$ & $46^{\circ} 08^{\prime} 24^{\prime \prime}$ & $\pm 40^{\prime \prime}$ \\
\hline $69^{\circ} 5^{8^{\prime}} 37^{\prime \prime}$ & $\pm 5^{\prime \prime}$ & $46^{\circ} 31^{\prime} 55^{\prime \prime}$ & $\pm 30^{\prime \prime}$ \\
\hline $69^{\circ} 54^{\prime} 59^{\prime \prime}$ & $\pm 5^{\prime \prime}$ & $46^{\circ} 55^{\prime} 05^{\prime \prime}$ & $\pm 60^{\prime \prime}$ \\
\hline $69^{\circ} 5^{\prime}$ o8 $8^{\prime \prime}$ & $\pm 5^{\prime \prime}$ & $47^{\circ} 18^{\prime} 27^{\prime \prime}$ & $\pm 30^{\prime \prime}$ \\
\hline $69^{\circ} 4^{8^{\prime}} 03^{\prime \prime}$ & $\pm 5^{\prime \prime}$ & $47^{\circ} 4^{I^{\prime}} 00^{\prime \prime}$ & $\pm 60^{\prime \prime}$ \\
\hline $69^{\circ} 43^{\prime} 55^{\prime \prime}$ & $\pm 5^{\prime \prime}$ & $4^{8^{\circ}}$ o $4^{\prime}$ o $5^{\prime \prime}$ & $\pm 30^{\prime \prime}$ \\
\hline
\end{tabular}

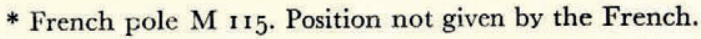

MS. received 4. May 1957

\section{REFERENCES}

I. Benson C. S., and Ragle, R. H. Measurements by SIPRE in 1955 of the accumulation markers of Expéditions Polaires Françaises in central Greenland. SIPRE Special Report, 19, 1956.

2. Bowditch, N. American practical navigator. Washington, D.C., U.S. Government Printing Office, I943, p. 169. 3. Victor, P.-E., and others. Campagne au Groenland 1950. Expéditions Polaires Françaises. Publications Préliminaires, [No.] 15, [1952], p. 65-86.

4. Holtzscherer, J.-J. Contribution à la connaissance de l'inlandsis du Groenland. rère partie, mesures séismiques. Paris, Expéditions Polaires Françaises, 1954.

5. Haefeli, R., and Brentani, F. Observations in a cold ice cap. Part II. Journal of Glaciology, Vol. 2, No. 19, 1956. p. $623-30$. 